\title{
DOI: http://dx.doi.org/10.33846/sf11404
}

Faktor Penghambat dalam Pelaksanaan Program VCT (Voluntary Counselling and Testing): A Literature Review

Nita Anggerina Putri Hi Setiawan

Magister Epidemiologi, Universitas Diponegoro; nitaputrisetiawan@ gmail.com (koresponden)

Mateus Sakundarno Adi

Bagian Epidemiologi, Fakultas Kesehatan Masyarakat, Universitas Diponegoro; adisakundarno@yahoo.com

\begin{abstract}
The prevalence of HIV/AIDS had been increasing due to the lack of awareness of people to use or access VCT services, especially those with high risk. Many factors affect people and people at high risk of accessing VCT services. The study aims to describe barriers that arise in the implementation of the VCT program. The research method was a literature review from electronic database such as Google Scholar, PubMed, and Science Direct. Keyword search included barrier, Voluntary Counseling and Testing, and HIV VCT. Selected 9 articles published from 2018 to 2020. The results of the study of all articles founded that barriers in the implementation of VCT in the form of lack of knowledge, fear, and shame when taking an HIV test, difficulty in communicating because of hearing impairment so that the information received was not enough, stigma from the community and health workers, barriers to limited operational hours of VCT services, lack of staff as program implementers, limited competence due to lack of training, and limited health infrastructure/facilities.
\end{abstract}

Keywords: barrier; VCT; HIV/AIDS

Prevalensi HIV/AIDS semakin meningkat karena kurangnya kesadaran orang-orang untuk memanfaatkan atau mengakses layanan VCT terutama mereka dengan risiko tinggi. Banyak faktor yang mempengaruhi masyarakat maupun orang dengan risiko tinggi dalam mengakses layanan VCT. Tujuan penulisan artikel ini adalah untuk menggambarkan tentang hambatanhambatan yang muncul dalam pelaksanaan program VCT. Metode penelitian adalah literature review dari database elektronik seperti Google Scholar, PubMed, dan Science Direct. Kata kunci pencarian antara lain menggunakan kata kunci barrier, Voluntary Counselling and Testing, dan VCT HIV. Terpilih 9 artikel yang dipublikasi tahun 2018 sampai 2020. Hasil penelitian dari semua artikel, diperoleh bahwa hambatan-hambatan dalam pelaksanaan VCT yaitu berupa kurangnya pengetahuan, rasa takut, dan malu jika melakukan tes HIV, kesulitan dalam berkomunikasi karena memiliki gangguan pendengaran sehingga informasi yang diterima pun kurang, stigma dari masyarakat serta petugas kesehatan, hambatan jam operasional layanan VCT yang terbatas, kurangnya jumlah staf sebagai pelaksana program, kompetensi yang terbatas karena kurang mengikuti pelatihan, serta infrastruktur/fasilitas kesehatan yang terbatas.

Kata Kunci: hambatan; VCT; HIV/AIDS

\section{PENDAHULUAN}

HIV (Human Immunodeficiency Virus) adalah infeksi yang menyerang sistem imunitas, khususnya sel darah putih yang disebut sel CD4. HIV menghancurkan sel CD4, melemahkan kekebalan terhadap infeksi seperti TBC dan kanker. Seseorang yang terinfeksi HIV dinyatakan sebagai penderita AIDS ketika menunjukkan gejala atau penyakit tertentu yang merupakan akibat penurunan daya tahan tubuh atau ketika melakukan tes darah CD4 nya $<200 / \mathrm{mm}^{3}$. (1)

Menurut UNAIDS (Joint United Nation Programme On HIV and AIDS) bahwa di Dunia pada akhir 2018 terdapat 37,9 juta orang hidup dengan HIV (36,2 juta orang dewasa dan 1,7 juta anak-anak), dan 770.000 orang di dunia meninggal karena HIV/AIDS. ${ }^{(2)}$ Kasus HIV di Indonesia tahun 2018 terdapat 640.000 orang hidup dengan HIV dengan jumlah kasus baru sebesar 46.000 orang dan jumlah orang yang meninggal karena AIDS sebanyak 38.000 orang. ${ }^{(3)}$

Salah satu program yang dilaksanakan untuk mencegah penularan HIV/AIDS adalah Voluntary Counselling and Testing (VCT) atau konseling dan tes sukarela. VCT merupakan komponen kunci dalam program HIV di negara maju maupun berkembang. VCT dijadikan sebuah intervensi yang memberi kesempatan seseorang untuk mengetahui status HIV mereka dan kemudian dirujuk kepada layanan perawatan, dukungan dan pengobatan (PDP). ${ }^{(4)}$

VCT merupakan pintu masuk untuk membantu setiap orang untuk mendapatkan akses semua pelayanan baik informasi, edukasi, terapi atau dukungan psikososial. VCT dikenal sebagai strategi yang efektif baik untuk pencegahan HIV/AIDS dan juga perawatan dilingkup Internasional. VCT juga bertujuan menyediakan layanan bagi masyarakat yang membutuhkan agar dapat memperoleh dukungan psikologis, pemberian informasi dan pengetahuan HIV/AIDS sehingga terjadi perubahan perilaku yang lebih sehat, aman dan bertanggung jawab. ${ }^{(4)}$

Tes HIV adalah langkah penting dalam penanganan HIV (diagnosis, hubungan dengan perawatan, keterlibatan dalam perawatan, retensi dalam perawatan, inisiasi terapi antiretroviral, dan penekanan virus) untuk semua populasi kunci. Sebagai contoh, identifikasi wanita yang terinfeksi HIV melalui tes HIV adalah langkah pertama untuk pencegahan penularan HIV dari ibu ke anak (PMTCT). ${ }^{(5)}$

Prevalensi HIV/AIDS semakin meningkat karena kurangnya kesadaran orang-orang untuk memanfaatkan atau mengakses layanan Voluntary Counselling and Testing (VCT) terutama mereka dengan risiko tinggi. Banyak faktor yang mempengaruhi masyarakat maupun orang dengan risiko tinggi dalam mengakses layanan VCT. ${ }^{(6)}$ 
Beberapa studi mengidentifikasi bahwa terdapat hambatan dan tantangan yang dihadapi ketika mengakses layanan VCT di negara-negara berkembang seperti Nepal salah satunya. Beberapa hambatan tersebut berupa sosial budaya dan juga hambatan geografis. ${ }^{(7)}$

Tujuan dari penulisan artikel ini adalah menggambarkan tentang hambatan-hambatan yang muncul dalam pelaksanaan program VCT, selain hambatan sosial budaya dan geografis yang sebelumnya telah disebutkan di atas. Diharapkan dari hasil literature review ini dapat menjadi masukan untuk para pembuat kebijakan dalam merencanakan, merancang, dan meningkatkan kualitas program/layanan VCT secara efektif untuk semua orang dan tepat sasaran. Serta dapat menekan jumlah kasus HIV/AIDS serta mengurangi penularannya.

\section{METODE}

Metode yang digunakan dalam penelitian ini adalah literature review. Sumber data penelitian ini berasal dari literatur yang diperoleh dari hasil penelitian (artikel penelitian) tentang Pelaksanaan Program Voluntary Counselling and Testing yang dipublikasikan di internet. Kriteria inklusi artikel yang digunakan adalah jurnal penelitian berbahasa Inggris, dapat diakses secara full text diterbitkan dalam kurun waktu tiga tahun terakhir (2018-2020). Sedangkan kriteria eksklusi adalah artikel yang bukan berbahasa Inggris, tidak dapat dibaca full text, dan yang lebih spesifik membahas tentang HIV/AIDS (penularan, penyebaran, serta dampak HIV).

Pencarian literatur dilakukan secara komputerisasi dengan database elektronik Google Scholar, PubMed, dan Science Direct. Kata kunci pencarian antara lain menggunakan kata kunci "barrier, Voluntary Counselling and Testing, dan VCT HIV". Setelah artikel tersebut ditemukan, selanjutnya dievaluasi sesuai kriteria dan ditelaah untuk di-review.

\section{HASIL}

Strategi pencarian yang dilakukan dengan mengidentifikasi database (dokumen full text, 3 tahun terakhir), diperoleh 9 artikel. Penelitian yang dilakukan di negara Ghana, Tanzania, Ethiopia, Indonesia, Namibia, Zimbabwe, Nigeria, dan dua penelitian dari China. Dari 9 penelitian tersebut, 3 di antaranya menggunakan desain cross sectional serta 1 desain cross sectional survey, kemudian 1 penelitian menggunakan desain kualitatif dengan FGD, 1 desain deskriptif kualitatif, 1 deskriptif survey, 1 menggunakan desain deskriptif kualitatif dan eksploratif, dan 1 penelitian lagi menggunakan desain eksploratif.

Tabel 1. Hasil review artikel

\begin{tabular}{|c|c|c|c|c|c|}
\hline No & Penulis, tahun, judul & Lokasi & Sampel & Desain & Kesimpulan \\
\hline 1. & $\begin{array}{l}\text { Christiana Asiedu et all. 2019. Assessment } \\
\text { of Knowledge and Attitudes of Expectant } \\
\text { Mothers towards HIV Screening and } \\
\text { Counselling at Jachie-Pramso in the } \\
\text { Ashanti Region of Ghana. }{ }^{(8)}\end{array}$ & $\begin{array}{l}\text { Ashanti, } \\
\text { Ghana. }\end{array}$ & 158 & $\begin{array}{l}\text { Deskriptif } \\
\text { survey }\end{array}$ & $\begin{array}{l}\text { Faktor yang mempengaruhi keputusan ibu hamil dalam } \\
\text { melakukan VCT adalah sikap dari tenaga kesehatan, } \\
\text { anggota komunitas, serta pasangan mereka sendiri. }\end{array}$ \\
\hline 2. & $\begin{array}{l}\text { Michael A Munga et all. 2019. Willingness } \\
\text { and Barriers to Voluntary Counselling And } \\
\text { Testing Among Self-Perceived Healthy } \\
\text { Adults In Tanzania. } .^{(9)}\end{array}$ & $\begin{array}{l}\text { Swahili, } \\
\text { Tanzania }\end{array}$ & 1.429 & $\begin{array}{l}\text { Cross } \\
\text { Sectional } \\
\text { survey }\end{array}$ & $\begin{array}{l}\text { Hambatan orang-orang dalam mengakses layanan VCT } \\
\text { di Tanzania yaitu stigma merupakan faktor utama, } \\
\text { kemudian jarak tempat tinggal dengan pusat layanan } \\
\text { VCT, kurangnya pengetahuan tentang HIV, staf yang } \\
\text { kurang kompeten dan keterbatasan pada infrastruktur } \\
\text { atau fasilitas kesehatan. }\end{array}$ \\
\hline 3. & $\begin{array}{l}\text { Asfaw Negero Erena et all. 2019. Factors } \\
\text { Affecting HIV Counselling and Testing } \\
\text { Among Ethiopian Women Aged 15-49. }{ }^{(10)}\end{array}$ & Ethiopia & 14.369 & $\begin{array}{l}\text { Cross } \\
\text { Sectional }\end{array}$ & $\begin{array}{l}\text { Stigma mempengaruhi akses layanan VCT pada } \\
\text { kalangan wanita di Euthopia. }\end{array}$ \\
\hline 4. & $\begin{array}{l}\text { Dinar Lubis et all. 2019. Private Midwives' } \\
\text { Perceptions of Barriers and Enabling } \\
\text { Factors to Voluntary Counseling and HIV } \\
\text { Testing in Bali, Indonesia. }{ }^{(11)}\end{array}$ & $\begin{array}{l}\text { Bali, } \\
\text { Indonesia }\end{array}$ & 15 & Kualitatif & $\begin{array}{l}\text { Hambatan yang dihadapi oleh bidan swasta terkait } \\
\text { dengan VCT yaitu hambatan berupa stigma, kemudian } \\
\text { hambatan institusional seperti jam operasional layanan } \\
\text { VCT. }\end{array}$ \\
\hline 5. & $\begin{array}{l}\text { Jason J Ong et all. 2019. Opportunities And } \\
\text { Barriers For Providing HIV Testing } \\
\text { Through Community Health Centers In } \\
\text { Mainland China: A Nationwide Cross- } \\
\text { Sectional Survey. }{ }^{(12)}\end{array}$ & China & 3.580 & $\begin{array}{l}\text { Cross } \\
\text { Sectional } \\
\text { survey }\end{array}$ & $\begin{array}{l}\text { Hambatan di pusat kesehatan komunitas yakni } \\
\text { kurangnya pelatihan (staf), serta sikap negatif (stigma) } \\
\text { oleh staf terhadap populasi kunci. }\end{array}$ \\
\hline 6. & $\begin{array}{l}\text { Shipanga Victoria K et all. } 2018 . \\
\text { Perceptions of Men with Regard to Human } \\
\text { Immunodeficiency Virus (HIV) Voluntary } \\
\text { Counselling and Testing, Windhoek. }{ }^{(13)}\end{array}$ & $\begin{array}{l}\text { Widhoek, } \\
\text { Namibia }\end{array}$ & 9 & $\begin{array}{l}\text { Deskriptif } \\
\text { Kualitatif, } \\
\text { dan } \\
\text { eksploratif }\end{array}$ & $\begin{array}{l}\text { Faktor yang menjadi penghambat pria dalam mencari } \\
\text { layanan konseling tes HIV di fasilitas umum adalah } \\
\text { hambatan sosial dan perilaku (takut akan hasil positif, } \\
\text { stigma) dan hambatan terkait budaya (rasa malu, } \\
\text { kepercayaan budaya di Negara tersebut). }\end{array}$ \\
\hline 7. & $\begin{array}{l}\text { Patricia Mutumburanzou et all. } 2019 . \\
\text { Voluntary Counselling and Testing Services } \\
\text { for Youths with Hearing Impairment: A } \\
\text { Case for Masvingo District in Zimbabwe. }{ }^{(14)}\end{array}$ & $\begin{array}{l}\text { Mavingo, } \\
\text { Zimbabwe }\end{array}$ & $\begin{array}{l}20 \\
\text { remaja, } \\
10 \\
\text { konselor }\end{array}$ & $\begin{array}{l}\text { Deskriptif } \\
\text { Kualitatif }\end{array}$ & $\begin{array}{l}\text { Hambatan akses layanan VCT pada anak muda dengan } \\
\text { gangguan pendengaran yaitu berupa kurangnya } \\
\text { informasi tentang HIV/AIDS (informasi spesifik terkait } \\
\text { layanan VCT). Yang kedua adalah hambatan } \\
\text { komunikasi karena konselor tidak dapat menggunakan } \\
\text { bahasa isyarat (tidak adanya penerjemah). }\end{array}$ \\
\hline 8. & $\begin{array}{l}\text { Bibiana N E et all. 2018. Knowledge, } \\
\text { Attitude and Factors Affecting Voluntary } \\
\text { HIV Counseling And Testing Services } \\
\text { Among Women Of Reproductive Age Group } \\
\text { In An Abuja Suburb Community, Nigeria. }{ }^{(15)} \\
\end{array}$ & Nigeria & 150 & Prospektif & $\begin{array}{l}\text { Faktor utama yang mempengaruhi pemanfaatan } \\
\text { layanan VCT oleh Kelompok Wanita usia reproduktif } \\
\text { yaitu stigma dan diskriminasi, sikap petugas } \\
\text { kesehatan/staf pengelola layanan kesehatan, lokasi } \\
\text { pusat VCT yang jauh, tingkat pendidikan, serta rasa }\end{array}$ \\
\hline
\end{tabular}




\begin{tabular}{|c|c|c|c|c|c|}
\hline No & Penulis, tahun, judul & Lokasi & Sampel & Desain & Kesimpulan \\
\hline & & & & & ragu akan kerahasiaan saat melakukan VCT. \\
\hline 9. & $\begin{array}{l}\text { Qi, Zhang et all. } 2020 . \\
\text { HIV Prevalence and Factors Influencing } \\
\text { the Uptake of Voluntary HIV Counseling } \\
\text { and Testing among Older Clients of Female } \\
\text { Sex Workers in Liuzhou and Fuyang Cities, } \\
\text { China, 2016-2017: A Cross-Sectional } \\
\text { Study.(16) }\end{array}$ & $\begin{array}{l}\text { Liuzhou } \\
\text { and } \\
\text { Fuyang, } \\
\text { China }\end{array}$ & 978 & $\begin{array}{l}\text { Cross } \\
\text { Sectional }\end{array}$ & $\begin{array}{l}\text { Para pelanggan wanita pekerja seksual yang berusia tua } \\
\text { tidak mengakses layanan VCT karena takut akan } \\
\text { diketahui oleh pasangan (istri) mereka bahwa mereka } \\
\text { menggunakan jasa seks komersial, yang kedua adalah } \\
\text { stigma dimana mereka yang memiliki stigma terhadap } \\
\text { orang dengan HIV, juga kecil kemungkinan untuk } \\
\text { mengakses layanan VCT. }\end{array}$ \\
\hline
\end{tabular}

Berdasarkan analisis yang telah dilakukan terhadap 9 artikel, diperoleh bahwa hambatan dalam pelaksanaan program VCT yang dirasakan oleh pasien maupun orang-orang yang belum pernah mengakses layanan VCT yaitu berupa stigma, baik itu stigma dari masyarakat maupun stigma oleh petugas kesehatan, kurangnya dukungan dari orang-orang terdekat, kurangnya pengetahuan tentang HIV/AIDS (lebih spesifik tentang VCT), jarak tempat tinggal dengan pusat layanan VCT yang jauh, hambatan terkait budaya, serta kurang informasi karena terbatasnya komunikasi mengenai VCT yang diterima oleh mereka yang mengalami gangguan pendengaran dimana konselor tidak dapat menggunakan bahasa isyarat.

Hambatan petugas kesehatan (bidan, petugas pada pusat kesehatan komunitas, konselor) dalam pelaksanaan VCT meliputi kurangnya pelatihan untuk staf, kurangnya staf yang kompeten, kurang fasilitas. Hambatan institusional berupa jam operasional layanan VCT, yang membatasi bagaimana dan kapan petugas kesehatan dapat merujuk ibu hamil untuk melakukan VCT, serta konselor yang tidak dapat menggunakan bahasa isyarat, sehingga komunikasi pemberian informasi tentang HIV maupun VCT tidak maksimal.

\section{PEMBAHASAN}

Konseling dan tes HIV dilaksanakan di Indonesia sejak tahun 2004, yaitu dengan pendekatan konseling dan tes HIV atas inisiatif klien atau yang dikenal dengan konseling dan tes HIV sukarela/VCT. Bagi mereka yang ingin mengetahui status HIV nya dapat melakukan tes secara sukarela. Konseling dan Tes HIV merupakan pintu masuk utama pada layanan pencegahan, perawatan, dukungan dan pengobatan. Dalam kebijakan dan strategi nasional, konsep akses universal telah dicanangkan untuk mengetahui status HIV, akses ke layanan pencegahan, perawatan, dukungan dan pengobatan HIV dengan visi "getting to zero", yaitu zero new HIV infection, zero discrimination, serta zero AIDS related death. ${ }^{(4)}$

Secara global diperkirakan separuh ODHA tidak mengetahui status HIV mereka, bahkan ODHA yang mengetahui status HIV mereka sering terlambat untuk memeriksanya. Kurangnya akses antara konseling, tes dan pengobatan HIV menyebabkan keterlambatan dalam pengobatan HIV yang sudah pada tahap AIDS. Keterlambatan dalam perawatan mengurangi kemungkinan mendapatkan hasil yang baik dan tingkat penularan akan tetap tinggi. ${ }^{(6)}$

Dalam pedoman pelaksanaan konseling dan tes HIV, tahapan pelayanan VCT yaitu konseling pre testing, testing HIV, dan konseling pasca testing. Pada tahapan konseling pre testing pasien bersama konselor mendiskusikan hal-hal yang terkait dengan informasi akurat dan lengkap tentang HIV/AIDS, perilaku beresiko, testing HIV dan pertimbangan yang terkait dengan hasil negatif atau positif. Tahap yang selanjutnya yaitu tahap testing HIV. Tahap testing HIV dalam VCT bertujuan untuk menegakkan diagnosis. Apabila hasil tes sudah diketahui maka tahapan yang dilakukan itu konseling pasca testing. Pada tahapan ini membantu pasien untuk memahami dan menyesuaikan diri dengan hasil tes.(4)

Kualitas konseling perlu dipantau dengan mentoring dan pembinaan yang teratur. Konseling diutamakan bagi mereka yang berisiko dan menolak tes, klien dengan kebutuhan khusus, serta setelah dilakukan tes HIV berupa konseling lanjutan bagi ODHA. ${ }^{(4)}$

Pada umumnya, layanan VCT diselenggarakan di tingkat komunitas sehingga lebih dekat menjangkau masyarakat yang membutuhkannya. Model layanan tersebut menekankan kesukarelaan klien untuk datang mencari layanan dan dengan persetujuan (informed consent). Layanan yang dilakukan mengacu pada prinsip 5C yaitu informed consent, confidentiality, counseling, correct test results, connections to, care, treatment and prevention services. ${ }^{(4)}$

Ketersediaan akses ke VCT dan kesadaran masyarakat tentang VCT adalah kunci sehingga pasien dengan HIV / AIDS menerima terapi antiretroviral (ART), dan mencegah penularan dengan perubahan perilaku. Konseling dirancang untuk membantu pasien dalam menafsirkan hasil tes laboratorium, untuk mengubah perilaku yang bertujuan pencegahan infeksi dan penularan HIV. Salah satu bidang yang menjadi fokus WHO saat ini adalah konseling dan tes HIV yang sangat berperan sebagai pintu masuk tahap pencegahan dan pengobatan. ${ }^{(17)}$

Berdasarkan hasil analisis dari 9 penelitian, dimana dalam penelitian tersebut dikemukakan bahwa hambatan dalam pelaksanaan Voluntary Counselling and Testing yang dirasakan oleh pasien, orang-orang yang belum pernah mengakses layanan VCT, ataupun petugas kesehatan sebagai pelaksana program. Hambatan-hambatan tersebut terdiri dari hambatan personal, hambatan sosial, serta hambatan institusional.

Pelaksanaan Voluntary Counselling and Testing dimana mengenai akses layanan seringkali terkendala oleh stigma baik itu stigma dari masyarakat maupun dari petugas kesehatan. Stigma HIV adalah salah satu kendala utama sejak pertama kali terdiagnosa lebih dari 30 tahun yang lalu. Penelitian telah menunjukkan bahwa stigma dan diskriminasi HIV menghambat orang dengan HIV mengungkapkan status HIV mereka kepada keluarga atau pasangan mereka, mencari informasi, pengobatan, dan pencegahan HIV. (18) $^{(1)}$

Joint United Nations Programme on HIV/AIDS mendefinisikan stigma HIV sebagai keyakinan, perasaan dan sikap negatif terhadap orang dengan HIV, kelompok yang terkait dengan orang dengan HIV dan populasi kunci lainnya yang 
berisiko lebih tinggi terhadap infeksi HIV, seperti pengguna napza suntik, pekerja seks, pria yang berhubungan seks dengan pria dan waria. Stigma sosial dan diskriminasi terhadap ODHA tidak hanya memperburuk kondisi pasien, tetapi juga menjadi hambatan untuk program pencegahan dan penanggulangan HIV/AIDS. Stigma bukan saja berasal dari masyarakat tetapi adapula stigma dari petugas kesehatan sehingga menyebabkan orang-orang takut untuk mengakses layanan VCT. ${ }^{(19)}$

Hambatan lain juga dialami oleh remaja dengan gangguan pendengaran dimana karena keterbatasan komunikasi menyebabkan kurangnya informasi mengenai VCT yang mereka peroleh. Konselor tidak dapat menggunakan bahasa isyarat dan tidak ada penerjemah yang dapat membantu dalam proses tersebut sehingga hasilnya tidak akan maksimal. Remaja dengan gangguan pendengaran tidak menikmati hak istimewa ketika mereka melakukan dites HIV dengan sukarela. Mereka mengunjungi rumah sakit untuk berobat ketika mereka sakit atau hamil. Banyak dari mereka ketika melakukan tes HIV, kemudian tidak mendapatkan hasil mengenai status mereka. Penelitian sebelumnya yang dilakukan di London bahwa orang dengan gangguan pendengaran dapat dirugikan dalam memanfaatkan sepenuhnya layanan kesehatan di London. Orang-orang tersebut lebih mungkin menderita masalah kesehatan yang buruk daripada masyarakat lainnya karena mereka menghadapi hambatan dalam mengakses layanan kesehatan seperti VCT yang seharusnya dapat diakses oleh semua orang. Sebagian besar orang dewasa muda dengan gangguan pendengaran tidak mengetahui status mereka. Hampir semua staf layanan VCT mengatakan bahwa mereka tidak dapat berkomunikasi dalam bahasa isyarat. ${ }^{(20)}$

Pusat layanan VCT tidak memiliki struktur atau program khusus untuk remaja dengan gangguan pendengaran. Mereka tidak menghadiri kampanye pencegahan HIV karena kampanye tersebut kebanyakan hanya menargetkan orangorang yang dapat mendengar secara normal, menyebabkan mereka tidak mendapatkan informasi-informasi yang sangat penting. Sebagian besar remaja dengan gangguan pendengaran tidak mendapat manfaat dari konselor profesional tetapi ketika memang sangat dibutuhkan mereka mendapatkan konseling oleh anggota keluarga terutama para ibu. Para remaja yang tidak pernah bersekolah mengungkapkan ketidaktahuan ketika datang untuk menerima layanan dari pusat VCT. ${ }^{(14)}$

Hambatan yang diperoleh berdasarkan hasil analisis dari 9 artikel penelitian, sejalan dengan hasil penelitian yang dilakukan di Kenya bahwa perempuan yang mengakses VCT rendah. Kendala utama dalam mengakses VCT yang dihadapi oleh perempuan itu adalah karena keterbatasan peran gender, tidak memadainya akses di desa, infrastruktur, dan pelatihan petugas kesehatan yang harus ditangani serta stigma yang terkait dengan HIV/AIDS. ${ }^{(21)}$ Selain itu, hambatan juga disebabkan oleh kurangnya pemahaman tentang HIV-AIDS dan VCT terutama untuk orang-orang berisiko tinggi. ${ }^{(22)}$

Petugas kesehatan sebagai pelaksana layanan VCT juga menghadapi hambatan yaitu berupa kurangnya pelatihan untuk staf, kurangnya staf yang kompeten, kurang fasilitas kesehatan, hambatan institusional berupa jam operasional layanan VCT yang membatasi bagaimana dan kapan petugas kesehatan dapat merujuk ibu hamil untuk melakukan VCT, serta konselor yang tidak dapat menggunakan bahasa isyarat sehingga komunikasi pemberian informasi tentang HIV maupun VCT tidak maksimal.

Evaluasi dilakukan di Afrika Selatan dan Tanzania, diperoleh bahwa fasilitas di mana beberapa staf telah menerima pelatihan pada Youth Friendly Services, namun tetap saja masih kurangnya staf terlatih yang menjadi penghalang atau hambatan dalam pelaksanaan program kesehatan, perlunya melatih lebih banyak atau idealnya semua petugas kesehatan di setiap fasilitas kesehatan. ${ }^{(23,24)}$ Masalah utama adalah perlunya menyediakan pelatihan kepada semua petugas kesehatan yang memiliki kendala sumber daya, terutama di negara berpenghasilan rendah dan menengah. Upaya perlu mencakup penyediaan pelatihan untuk semua petugas layanan kesehatan, serta yang baru sejauh mungkin. Agar hal tersebut dapat berkesinambungan, maka pelatihan ini juga harus dimasukkan ke dalam kurikulum untuk pelatihan dasar petugas kesehatan.

Tersedianya infrastruktur atau fasilitas kesehatan merupakan kebutuhan penunjang dalam keberhasilan suatu program, tujuan program dapat tercapai sesuai dengan yang telah direncanakan. Setiap organisasi baik itu dalam bidang kesehatan ataupun bidang lainnya dalam menyelenggarakan kegiatannya membutuhkan sarana dan prasarana yang cukup dengan kualitas yang baik untuk mencapai tujuan yang diharapkan. Tanpa ketersedian sarana dan prasarana, suatu kegiatan tidak dapat diselesaikan sebagaimana seharusnya, bahkan akan mengalami hambatan atau tidak berjalan dengan lancar. ${ }^{(25)}$

Hambatan berikutnya mengenai jam operasional layanan VCT, terkait dengan studi di Ambarawa, sarana dan prasarana Klinik CST dinilai belum baik oleh pasien yaitu belum tersedia jam layanan VCT pada sore hari. Jam kerja layanan konseling dan testing terintegrasi dalam jam institusi pelayanan kesehatan setempat. Jumlah konselor yang cukup akan sangat membantu agar klien tidak harus menunggu lama ketika hendak mengakses layanan VCT. Layanan konseling penjangkauan dilakukan atas kesanggupan jam kerja para penjangkau dan ketersediaan waktu klien. Sebaiknya jam pelayanan tersedia di pagi dan sore hari sehingga mempermudah akses klien, di fasilitas kesehatan dengan keterbatasan sumber daya, maka konseling dan testing tidak dapat dilakukan setiap hari kerja. Oleh karena itu jam kerja VCT disesuaikan dengan jam kerja pelayanan kesehatan lain yang terkait konseling dan testing seperti KIA, TB, IMS, IDU. Pelayanan VCT tidak bisa buka dari pagi sampai sore hari dengan alasan bahwa jumlah SDM terbatas, selain itu klien/pengunjung VCT bukan merupakan pasien yang gawat darurat, yang harus segera mendapatkan pelayanan, tetapi bisa dilakukan di lain waktu yang penting klien dalam situasi yang tidak sibuk, sehingga tidak mengganggu pekerjaannya, apalagi sekarang kebanyakan orang bekerja hanya 5 hari kerja, sehingga bisa memeriksakan diri ke klinik VCT pada hari sabtu. ${ }^{(26)}$

\section{KESIMPULAN}

Berdasarkan hasil telaah kesembilan artikel di atas, maka dapat disimpulkan bahwa faktor-faktor yang menjadi penghambat dalam pelaksanaan program VCT yaitu berupa hambatan personal yang berasal dari orang itu sendiri misalnya kurangnya pengetahuan, rasa takut dan malu jika melakukan tes HIV, kesulitan dalam berkomunikasi karena memiliki 
gangguan pendengaran (hearing impairment) sehingga informasi yang diterima pun kurang. Hambatan sosial yang paling utama dan umum terjadi yaitu stigma dari masyarakat serta petugas kesehatan sehingga menyebabkan orang enggan untuk mengakses layanan VCT. Hambatan yang terakhir adalah hambatan institusional terkait dengan jam operasional layanan VCT yang terbatas sehingga untuk orang yang bekerja atau sekolah susah untuk menyesuaikan dengan jadwal tersebut. Kemudian kurangnya jumlah staf sebagai pelaksana program, kompetensi yang terbatas karena kurang mengikuti pelatihan terkait program, serta infrastruktur/fasilitas kesehatan yang terbatas. Program pencegahan HIV yang efektif diperlukan upaya yang signifikan untuk mengidentifikasi dan menghapus semua penyebab mendasar stigma dan diskriminasi terhadap orang dengan HIV, program atau layanan harus tepat sasaran, serta mudah dan ramah diakses semua orang.

\section{DAFTAR PUSTAKA}

1. World Health Organization (WHO). Overview HIV/AIDS. 2020.

2. UNAIDS. AIDS by the Number. 2019.

3. UNAIDS. Country Indonesia. 2019.

4. Kementrian Kesehatan Republik Indonesia. Pedoman Pelaksanaan Konseling dan Tes HIV. 2014. 7 p.

5. S Thierman, Chi BH, Levy JW, Goldenberg RL, Stringer JSSM. Individual Level Predictors for HIV Testing Among Antenatal Attendees in Lusaka, Zambia. Am J Med Sci. 2016;332 (1):13-7.

6. Darmawansyah, Suci R, Muh S, Balqis AA. The Analysis of Factors Affecting the Use of VCT Service for High-Risk Group Infected with HIV/AIDS in Makassar. Int J Res Heal Sci. 2014;(2):5.

7. Preeti KM, Peng BTB. Voluntary Counseling and Testing (VCT) Services and Its Role in HIV/AIDS Prevention and Management in Nepal. South East Asia J Public Heal. 2013;3 (1):10-6.

8. Asiedu C, Agyemang EO, Agyei EA. Assessment of Knowledge and Attitudes of Expectant Mothers towards HIV Screening and Counselling at Jachie-Pramso in the Ashanti Region of Ghana. World J AIDS. 2019;09(04):183-94.

9. Munga M, Urassa J, Kisoka W, Mutalemwa P. Willingness and Barriers to Voluntary Counselling and Testing Among Self-Perceived Healthy Adults in Tanzania. East African Heal Res J. 2019;3(1):16-23.

10. Erena AN, Shen G, Lei P. Factors affecting HIV counselling and testing among Ethiopian women aged 15-49. BMC Infect Dis. 2019;19(1):1-12.

11. Lubis D, Wulandari LPL, Suariyani NLP, Adhi KT, Andajani S. Private Midwives' perceptions of barriers and enabling factors to voluntary counseling and HIV Testing in Bali, Indonesia. Kesmas. 2019;14(1):14-20.

12. Ong JJ, Peng MH, Wong WW, Lo YR, Kidd MR, Roland M, et al. Opportunities and barriers for providing HIV testing through community health centers in mainland China: A nationwide cross-sectional survey. BMC Infect Dis. 2019;19(1):1-9.

13. Shipanga Victoria K, Nauiseb Taimi KJM. Perceptions of men with regard to Human Immuno Deficiency Virus (HIV) voluntary counselling and testing, Windhoek. 2016;7(3):54-9. Available from: http://41.205.129.132/handle/11070/1701

14. Mutumburanzou P. Voluntary Counselling and Testing Services for Youths with Hearing Impairment: A Case for Masvingo District in Zimbabwe. Int J Acad Res Bus Soc Sci. 2019;8(2):298-308.

15. Bibiana NE, Emmanuel PO, Amos D, Ramsey YM, Idris AN. Knowledge, attitude and factors affecting voluntary HIV counseling and testing services among women of reproductive age group in an Abuja Suburb community, Nigeria. Med J Zambia. 2018;45(1):13-22-22.

16. Zhang Q, Fu YS, Liu XM, Ding ZQ, Li MQ, Fan YG. HIV Prevalence and Factors Influencing the Uptake of Voluntary HIV Counseling and Testing among Older Clients of Female Sex Workers in Liuzhou and Fuyang Cities, China, 20162017: A Cross-Sectional Study. Biomed Res Int. 2020;2020.

17. World Health Organization. National AIDS Programs: A Guide to Indicators for Monitoring and Evaluating National HIV/AIDS Prevention Programs For Young People. 2004.

18. Kuteesa MO, Wright S, Seeley J, Mugisha J, Kinyanda EKF et al. Experiences of HIV-Related Stigma Among HIVPositive Older Persons in Uganda-A Mixed Methods Analysis. SAHARA J. 2014;11 (1):126-37.

19. UNAIDS. Programme on HIV/AIDS. Guidance note Reduction of HIV Related Stigma and Discrimination. 2014.

20. Boff A. Access to Health Services for Deaf People. 2015. 29-30 p.

21. Namazzi J A. Determinants of Using Voluntary Counselling and Testing for HIV-AIDS in Kenya. J Manag Policy Pract. 2011;(2):1-9.

22. Purwaningsih, Misutarno SNI. Analisis Faktor Pemanfaatan VCT pada Orang Risiko Tinggi HIV-AIDS. JurnalNers. 2011;6 (1):58-67.

23. Matthews C, Guttmacher S, Fisher A, Mtshizana Y, Nelson T, McCarthy JDV. The Quality of HIV Testing Services for Adolescents in Cape Town, South Africa: Do Adolescent-Friendly Services Make a Diference? JAdolesc Heal. 2009;44:188-90.

24. Renju J, Andrew B, Kishamawe C, Kato C, Changalucha J OA. A Process Evaluation of The Scale Up of a Youth Friendly Health Services Initiative in Northern Tanzania. J Int AIDS Soc. 2010;13:32:5-10.

25. Rosdiana A I, Raharjo BBIS. Implementasi Program Pengelolaan Penyakit Kronis (Prolanis). HIGEIA. 2017;1(3):140-50.

26. Susanti Rini KS. Pelayanan Klinik Voluntary Counseling and Testing (VCT) Di Rumah Sakit Umum Daerah Ambarawa Kabupaten Semarang Tahun 2017. Indones J Midwivery. 2018;1 (1):5-7. 